\title{
組織内照射を施行した口腔扁平上皮癌における組織学的所見と 局所制御率との関係について
}

\author{
梅田正博・横尾聡・大森昭輝・寺延治 \\ 中西孝一・岛田桂吉・吉田峰男*

\section{A study of the correlation between histological findings and local cure rate in squamous cell carcinoma of oral cavity treated with interstitial irradiation}

\author{
Masahiro UMEDA $\cdot$ Satoshi Yokoo - Akiteru OMorI \\ Osamu Teranobu $\cdot$ Koichi NaKanishi $\cdot$ Keikichi Shimada \\ Mineo Yoshida*
}

\begin{abstract}
A clinicopathological study was made of the correlation between histological findings of the biopsy specimen and local cure rate of 60 cases of oral squamous cell carcinoma treated with interstitial irradiation. The following findings were obtained.

1. Local cure rate with interstitial irradiation was $82 \%$ in $\mathrm{T} 1$ cases, $83 \%$ in early-T2(21 $\sim 30 \mathrm{~mm})$ cases, $64 \%$ in advanced $-\mathrm{T} 2(31 \sim 40 \mathrm{~mm})$ cases, and $25 \%$ in $\mathrm{T} 4$ cases.

2. Moderately or poorly defferentiated type showed lower local cure rate than well differentiated type.

3. Diffuse invading type showed lower local cure rate than clear borderline type.

4. These results suggest that the application of interstitial irradiation should be decided in view of histological findings as well as TNM classification.
\end{abstract}

Key words: oral cancer (口膑痛), interstitial irradiation (組織内炤射), histological findings (組瀻学的所見)

\section{はじめに}

П腔瘦の治㹉恃，再建外科の進少に伴い外科的切除が

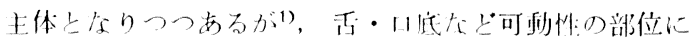

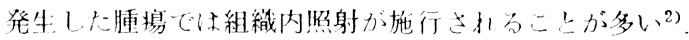

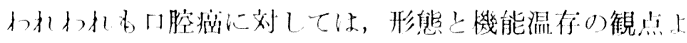

神戸大学医学初口腔外科学諈幽

( (1:任：島田桂吉教授)

* 蹱紡記念病院放射線科

（主任・吉田岞男部長）

Department of Maxillofacial Surgery, Kobe University School of Medicine(Chief: Prof. Keikichi Shimada)

* Department of Radiation Therapy, Kanebo Kinen Hospital (Chief: Mineo Yoshida)
り可能な限り組織内照射を行ってきたが，早期例でも局 所非制御となることがある。今回，組織内照射を施行し た口腔粘膜扁平上: 皮癌60例の臨床病理学的検討, 特に治 療前の原発菓組䄉学的所見亡局所制御率との阙斬性につ

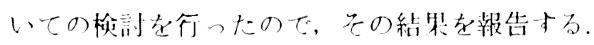

\section{対象症例および研究方法}

対象症例は1980～1989年の10年間に，神戸大学医学部 付愿病院函科口腔外科を受㟝した口腔粘膜扁平上皮癌 1 次掟例 205 例の5 万, 原発巣に対して組織内照射が施行 された 60 例である。部位別では舌50例, 口底 6 例, 頪粘 膜 4 例で，これは同時期の舌癌の $59 \%$ ， 口底癌の $17 \%$, 煩粘膜癌の $46 \%$ に相当する（表 1 ）。年跲は29～79歳(平 均57歳), 男女比は 1.5:1 と男性にやや多かった。 T分 類では T1：22例, T2：34例, T4：4例と, ほとんどが 
表 1 組瀻内巽射症例

\begin{tabular}{|c|c|}
\hline 原発部位 & 症例 \\
\hline 舌 & 50 例 \\
\hline 口底 & 6例 \\
\hline 槙粘膜 & 4例 \\
\hline 計 & 60 例 \\
\hline
\end{tabular}

神戸大学医学部口腔外科学教室（1980～1989年)

表 2 TNM 分類

\begin{tabular}{l|rrrr}
\hline & T1 & T2 & T4 & 計 \\
\hline N0 & 18 & 14 & - & 32 \\
N1 & 2 & 17 & 2 & 21 \\
N2b & 1 & 1 & 1 & 3 \\
N2c & 1 & 2 & 1 & 4 \\
\hline 計 & 22 & 34 & 4 & 60 \\
\hline
\end{tabular}

表 3 照射方法

\begin{tabular}{|c|c|c|c|c|}
\hline 照射方法 & $\mathrm{T} 1$ & $\mathrm{~T} 2$ & $\mathrm{~T} 4$ & 計 \\
\hline 組織内昭射単独 & 14 & 16 & - & 30 \\
\hline 組織内照射十聜内炤的 & 4 & 5 & - & 9 \\
\hline 組織内炤射十外炤射 & 4 & 12 & 4 & 20 \\
\hline 組織内炤射＋腔内沿射＋外炤射 & - & 1 & - & 1 \\
\hline 計 & 22 & 34 & 4 & 60 \\
\hline
\end{tabular}

$\mathrm{T} 2$ 以下の症例であり， N 分類では N0 が32例と過半数 を占めていたが，N1 が21例，N2 が7例文られた（表 2).これらの症例の治療前の臨床所見・組緎学的所 見と経過・予後化ついて检討した。な技，組織学的所 見として，分化度と浸潤様式を検討した，浸潤様式は Jakobsson ${ }^{3)}$, Willén') らの分類伤じたが，grade-1 は 症例数も少なく grade-2 と本質的に 同一のものと考光 られるため，呵者をとめて境界明睹型（W型）とし， grade-3 を中間型 (M型)，grade-4 をびまん性漫潤型 （D型）とした（写真 1$)$.

\section{結}

\section{果}

\section{1. 照射方法}

照射方法は可能ならば組織内照射単独としたが，腫瑒 が大きい場合や，病床の関係で入院までに日数がかかる 場合は，外照射や電子線腔内照射を併用した（表 3). 組織内照射の線源は ${ }^{226} \mathrm{Ra}$ 針をたは ${ }^{137} \mathrm{Cs}$ 針を使用乙 た。なお T4の 4 例は本来手術の適応であるが，高跲， 患者の希望などの理由で組織内照射が施行されたもので

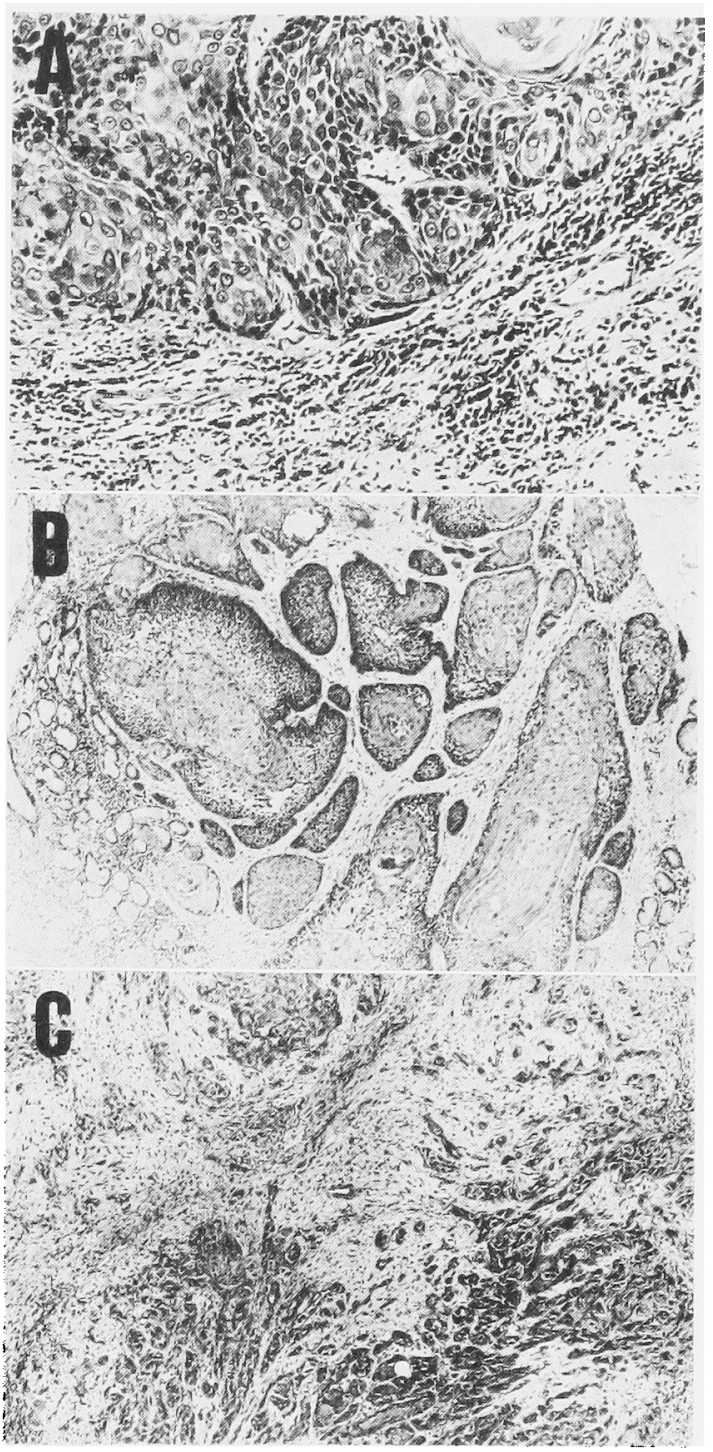

\section{写真 1 漫润样式}

A：境界明嘹型 (W型)， B：中間型（M型）,

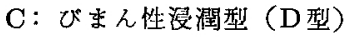

ある、頸部転移に対しては原則として頸部郭清を施行し た。

\section{2. 原発巣制御について}

T分類別の原発巣制御率を Kaplan-Meier 法に準じて 算出した（図 1)，5年累積制御率は，T1: $11 \%$ ，最大 径 21 30 mm の early-T2:79\%，31 40 mm の advanced-T2 : 47\%，T4:25\%であった。このように 30 $\mathrm{mm}$ 以下の腫熍では比較的制御率は良好であったが，30 $\mathrm{mm}$ 以下であっても 45 例中 8 例 $(18 \%)$ に原発巣再発を 認めている。これら原発巣が小さくても再発をきたした 
表 4 原発部位と制御率

\begin{tabular}{cc}
\hline 原発部位 & 制御率 \\
\hline 舌 & $29 / 36(81 \%)$ \\
口 底 & $5 / 5 \quad(100 \%)$ \\
煩粘膜 & $3 / 4 \quad(75 \%)$ \\
\hline 計 & $37 / 45(82 \%)$ \\
\hline
\end{tabular}

* T1 および early-T2 症例 45例

表 5 臨床視診型と制御率

\begin{tabular}{cc}
\hline 臨床視䧐型 & 制御率 \\
\hline 外向型 & $15 / 17(88 \%)$ \\
内向型 & $14 / 18(78 \%)$ \\
不 明 & $8 / 10(80 \%)$ \\
\hline
\end{tabular}

*T1 拈よび early-T2 症例 45例

表 6 照射方法

\begin{tabular}{lcc}
\hline \multicolumn{1}{c}{ 照射方法 } & 制御群(37例) & 再発群(8例) \\
\hline 組織内照射単独 & 20 例 & 6 例 \\
組織内炤射十腔内照射 & 8 例 & 1 例 \\
組織内照射 + 外照射 & 9 例 & 1 例 \\
\hline
\end{tabular}

* T1 扰よび early-T2 症例 45例

表 7 平均照射線量

\begin{tabular}{crc}
\hline & 制御群(37例) & 再発群( 8 例) \\
\hline 組織内照射 & $59 \mathrm{~Gy}$ & $63 \mathrm{~Gy}$ \\
腔内炤射 & $4 \mathrm{~Gy}$ & $5 \mathrm{~Gy}$ \\
外炤射 & $7 \mathrm{~Gy}$ & $7 \mathrm{~Gy}$ \\
\hline \multicolumn{1}{c}{ 計 } & $70 \mathrm{~Gy}$ & $75 \mathrm{~Gy}$ \\
\hline
\end{tabular}

* T1 および early-T2 症例 45例

拉例はどのよらな特改を有していたのたららか。

T1 拈よび early-T2 症例の発生部位と再発との四係

在表4に示した。舌，口底，煩粘膜で制御率に善はな く, 舌嵒再発の 7 例はすべて分界清の前方, 煩粘膜癌再 华の 1 例为煩粘膜の中央部に発生した症例で，再発症例 は後方型に多いといら上らな傾向は認められなかった。

これは舌根部へ深く浸潤しているような怔例は，最初よ

り手術の適応となるためと思われた。

T1 および early-T2 症例の臨床視診型と原発单再発 との四係を表 5 に示した。臨床視診型は乳頭型・白板 型・肉芽型在外向型，膨隆型・潰演型を内向型とした。 内问型でやや再発が多かったが，有意差はなかった。

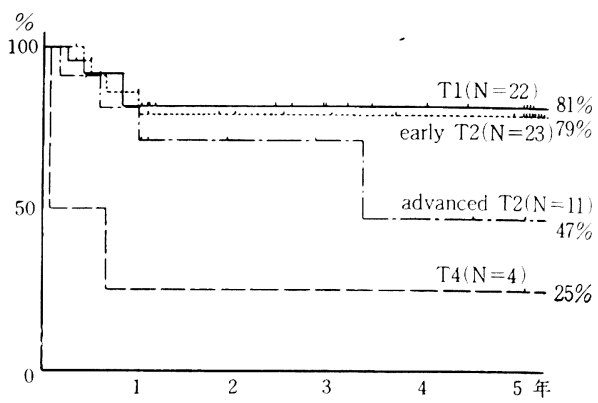

図 1 原発巣累稓制御率

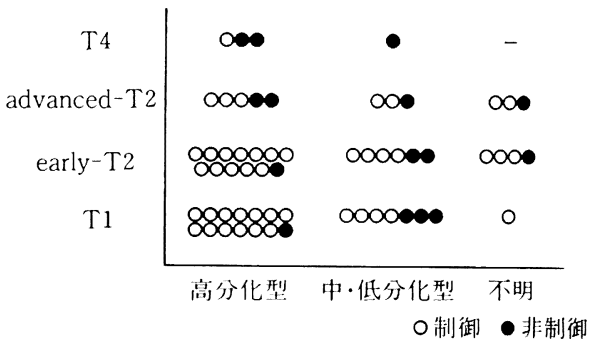

図 2 分化度と原発采制御率

T1 および early-T2 症例の照射方法抌よび照射線量 と原発巣再発との関係を表 6,7 に示した。制御群 37 例 と再発群 8 例との間に特に差異は認められず，再発症例 で線量が不足しているというような傾向はなかった。

以上のよらに， $30 \mathrm{~mm}$ 以下で組織内照射後に再発が みられた症例の臨床所見や治療法を検討したが, 制御例 との間に差異を見い出すことはできなかった。

次に組織学的所見について検討した。 まず，分化度と 制御率との関係を検討したが，今回の検討症例の大部分 が高分化型であった。これは舌癌では高分化型が多いこ とに加えて, 中分化型や低分化型の症例は初喨時より頸 部リンパ節転移が進行していることが多く，手術療法が 選択されたことによるものと思われた。

分化度と制御率との関係を图 2 に示す。机中分化型 と低分化型は症例数が少ないためまとめて検討した。 T1 拈よび carly-T2 症例では，高分化型の27例中25例 (93\%) が制御されたのに対し，中・低分化型では13 例 中 8 例 $(62 \%)$ と制御率は低い傾向がみられた。

次に浸潤様式と原発巣制御率との関係を図了に示す。 $W$ 型では T1 および early-T2 の 17例全例が制御でき たのに対し， M型では 8 例中 7 例 $(87.5 \%)$, D型では 13 例中 8 例 $(61.5 \%)$ となり，特にD型の制御率が低か った.

以上のように，組織所見と原発紧制御率との間には密 接な関連があり，T1 扣よび early-T2 症例では，分化 
表 8 組織学的所見と原発坚制御率

\begin{tabular}{lrc}
\hline & 高分化型 & 中・低分化型 \\
\hline $\mathrm{W}$ 型・ $\cdot \mathrm{M}^{\text {型 }}$ & $21 / 21(100 \%)$ & $3 / 4(75.0 \%)$ \\
$\mathrm{D}$ 型 & $4 / 6(66.7 \%)$ & $4 / 7(57.1 \%)$ \\
\hline
\end{tabular}

T1 括よび early-T2 症例 38例

（組織所見不明症例を除く）

表 9 非制御症例の 2 次治療と予後

\begin{tabular}{|c|c|c|c|c|}
\hline 初診時 $\mathrm{T}$ 分類 & \multicolumn{2}{|c|}{2 次治療 } & 子 & 後 \\
\hline \multirow[t]{2}{*}{$\mathrm{T} 1$} & 手 術 & 3 例 & 良好 & 3 例 \\
\hline & 外照射 & 1例 & 不良 & 1例 \\
\hline \multirow{3}{*}{$\mathrm{T} 2 \cdot \mathrm{T} 411$ 例 } & $\begin{array}{l}\text { 手 術 } \\
\text { cryosur }\end{array}$ & $\begin{array}{l}\text { 4例 } \\
\text { ry 2例 }\end{array}$ & \multirow{3}{*}{ 不良 } & \multirow{3}{*}{11 例 } \\
\hline & 外照射 & 2 例 & & \\
\hline & 非治療 & 3例 & & \\
\hline
\end{tabular}

度：高分化型・浸潤様式：W型またはM型の場合は21例 全例が制御可能であったが，高分化型でも浸潤様式D型 の場合や，分化度が中または低分化型の場合は制御率は 低くなることがあきらかになった（表 8 ）.

\section{3. 再発後の二次治療について}

組織内照射後再発がみられた15例の二次治療について 検討した（表 9）。T1 で再発がみられた 4 例の二次治療 は, 手術 3 例, 非治療 1 例で, 手術を施行した 3 例は救 命できた。T2 以上で再発がみられた11例の二次治療は, 手術 4 例, 外照射 2 例, cryosurgery 2 例, 非治療 3 例 で，11例全例とも原発巣の制御はできなかった。結局二 次治療も含めた最終的な原発巣制御率は, T1 で22例中 21 例 $(95.5 \%)$, T2 で 34例中 26 例 $(76.5 \%)$, T4 で 4 例中 1 例 $(25.0 \%)$ となった。

\section{4. 頸部転移巣制御について}

当科では, $N(+)$ 症例に対しては, 原則として組織内 照射後全頸部郭清を行い, $N(-)$ 症例に対しては, 予防 郭清や予防照射は施行せず政重な経過観察を行らことと している。

初診時 $N(+)$ で原発辢が制御できた症例は18例で， このうち頸部非制御となったのは2 例であった。頸部朝 清は照射終了後できるだけ早期に行らよ5にしている が，頸部非制御となった 2 例は，どちらも advanced-T2 症例で，照射により原発巣が制御できたかとらかの判定 がなかなか得られず，頸部郭清の時期が遅れた症例であ る. 最近では, 高分化型, 浸潤様式W型で $30 \mathrm{~mm}$ 以下 の症例では，原発巣制御は汪ほ確史に行えると考之，照 射終了後臨床的に原発栄制御を確認できる時期まで待つ ことなしに，たたちに頸部郭清を施行している。一力，

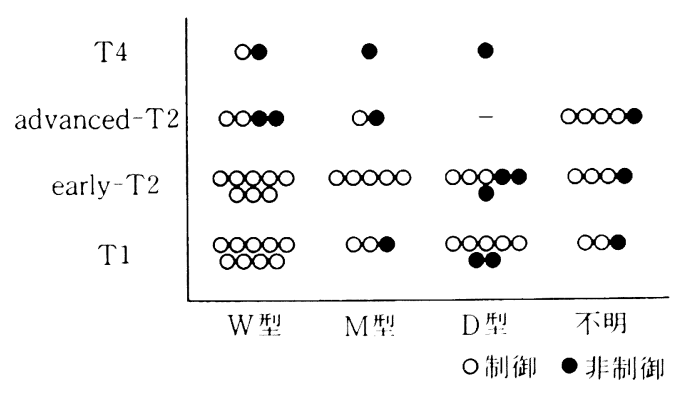

図 3 浸潤様式と原発集制御澡

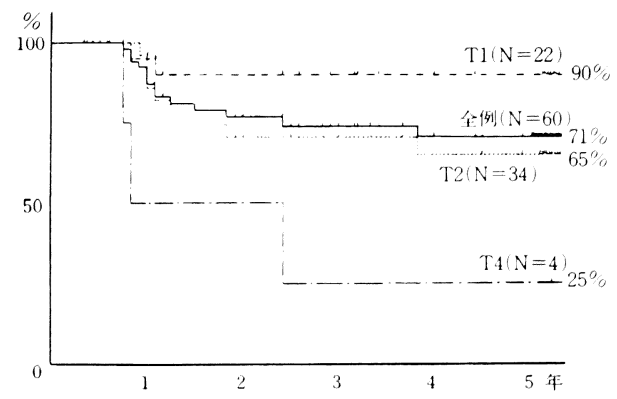

図 4 組織内照射症例の累程生存率

初診時 $N($ 一) で原発氷が制御できた 29 例の5ち経過中 に頸部後発転移をきたした症例は11例あり，9例は頸部 制御可能であったが 2 例は非制御となった。非制御症例 2 例は，1例は経過観察が不十分で手術時期が遟れた症 例でも51例は高路者のため保存的舌骨上郭清にとと めた症例であった。

\section{5. 生存率}

Kaplan-Meier 法に上る累積生存摔曲線を图 4に小 す。 5 年生存率は T1 : 90\%, T2：65\%, T4: 25\%で, 全症例では71\%であった，死亡原因は，原発巣死が最も 多く，初回治療法の選択が重要であると思机た。

\section{考察}

舌癌に対する小線源治療はほぼ確立され，原発栄制御 率は最近では約60 85\% と良好な成嚗が報告されてい る 年，われわれの症例でも舌，口底，賛粘膜あわせて 60例中45 $(75 \%)$ 例で原発巣制御が得られた。

組織内照射症例の原発巢制御に関与る内子として最も 重要なものは腫瘍の大きさで, T3よりも T1・T2 のほ らが，立体刺入より一面刺入の汪らが，また深澾度が大 きいものより小さなもののほらが高い制御率が報告され ている。しかし池田の報告 ${ }^{13)}$ では長径 $12 \mathrm{~mm}$ 以下, 厚 又 $8 \mathrm{~mm}$ 以下の舌癌 22 例中 $18 \%$ に，鎌田の報告12)では 
長径 $20 \mathrm{~mm}$ 以下, 厚2 $10 \mathrm{~mm}$ 以下の舌癌 $\mathrm{N} 0$ 症例 19 例 中16\%に，また，今可のわれわれの検討症例においても 最大径 $30 \mathrm{~mm}$ 以下の 45 例中 8 例 $(18 \%)$ に局所再発が 認められ，早期例でも必ずしも御御できるとは限らな い。れらのことより, 大きさ以外にも原発栄制御に闒 与る因子があると考光られ，今回の検討を行った。杂の 結果, $30 \mathrm{~mm}$ 以下の早期例では, 腫瘍の発生部位, 肉 眼所見, 照射方法, 照射線量などの臨床所見や治療方法 は, 再発群と制御群との間に差はなかった。しかし組織

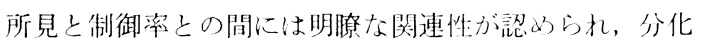
度の中等度以下のものや，浸澗粎式がびまん性を示与も のは, 制御率が低い結果であった。

これまで原発桇の組織学的所見と局所制御摔との関俰 を検討した報告はほとんどない、中村 ${ }^{11}$ は舌癌放射線治 療症例において, 組織学的悪性度と予後との関係を検討 して扣り，悪性度の高い症例は頸部転移が多く予後不良 であったと述べているが，原発栄制御率についてはあま り触れていない最近の再建外科の著しい進歩に伴い, 従来組織内照射を施行していたが積極的に手術を行らよ らになった施設もあり ${ }^{15)}$ ，組織内照射の適応について， TNM 分類だけではなく，組織学的所見も考虑に入れて 再検討する必要があるう。

組織内照射の成功のためには，(1) 腫埸が放射線感受 性があること，(2) 腫瘍の浸潤範囲の正確な把握，(3) 適正な刺入計画とその奏行などが必要である.今回の検 討で中・低分化型，びまん性浸潤型の症例が低い制御率 であった理由は，放射線感受性がもともと低いためか， あるいは視診・触診で判断される籁明を越えて組織学的 に浸潤していたためかは明確にすることはできない，照 射後の再発症例に対する salvage operation は, 初回の 手術に比べると切除籁曲が大きくなることが多く，その 成績もあまり良くない，そのため，特に最初の治獂力針 が重要となる。今後は，中・低分化型の症例，あるいは 高分化型であってもびまん性浸澗型の症例に対しては， 積極的に手術を行らか，組織内照射を行ら場合も刺入䇚 团を大きめにすることや，照射線量を增やすことで対処 していきたい。

\section{結語}

口腔粘膜扁平上皮癌の組織内照射施行症例60例につい

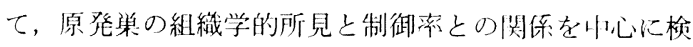
討を行い,以下の絬果を得た。

1. 原発楽制御は, T1 の22例中18例 $(82 \%)$, early-T2 $(21 \sim 30 \mathrm{~mm})$ の23例中19例 $(83 \%)$, advanced-T2 (31 $40 \mathrm{~mm})$ の11例中 7 例 $(64 \%), \mathrm{T} 4$ の 4 例门1 例 $(25 \%)$, 全症例では60例中45例 $(75 \%)$ で得られた。

2. $30 \mathrm{~mm}$ 以下の 45 例についてつると, 組織兴们所見 と局所制御率との間には明湟な网連性が涩められ，高分
化型で浸潤様式W型またはM型の21例は全例制御可能て あったが，高分化型でも浸潤様式がD型の症例や，中〜 低分化型の症例では制御率は低かった。

3. 再発症例に対与る二次治療の成績は悪かった。

4. 頸部転移果の制御寀は，初问転移16/18 (89\%)， 後発転移 7/9 (78\%) であった。

5. 以上のことより組織内照射の適応は，腫場の大き さだけではなく，組織学的所見も考慮のうえ決定される べきであると考えられた。

\section{引用文 献}

1）天津腿郎，非上健造：治療方針とその選択一手 術治療の立場から一. JOHNS 6: 213-216 1990.

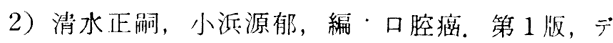
ンタルダィヤモンド社，東京，1989，400-408 頁.

3) Jakobsson, P.A., Eneroth, C.M., et al.: Histological classification and grading of malignancy in carcinoma of the larynx. Acta Rad Ther Phy Bio 12: 1-8 1973.

4) Willen, R., Nathanson, A., et al.: Squamous cell carcinoma of the gingiva. Acta Otolaryng 79: 146-154 1975.

5) 堀信一. 非上沿彦, 重松康. 舌癌 TxNo症 例の頸部リンパ節転移に関する検討。癌の臨枺 23: 507-510 1977.

6）森田皓三，林钽次郎，他：舌瘦の放射線治療 成縜。㿔の臨床 23：511-518 1977.

7）堀内淳一, 奥山武雄, 他：舌癌の放射線治療 -15 年間の治療成績の分析一日本医放会誌 37: 23-33 1977.

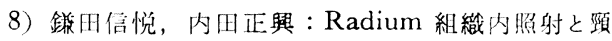
部㣀溥術に上る舌癌の治療。耳鼻と隔床 26 ： 544-556 1980.

9）堀内漫一, 竹田正宗, 他：口腔癌の放射線治療 の立場から又た頭频部瘦治療効果判定基淮案の 問題点。湢放 30：67-70 1985 .

10）西尾正道, 桜井智康, 他：小線源治療支主体々

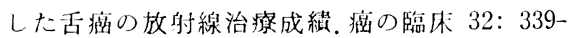
3441986.

11）中村太保：放射線治療成綃より久た舌瘦の予後 因子と病理組織像の閶速件について。阪大際学: 誌 31：209-224 1986.

12）锋田倍悦：舌瘦の治療力針の検刢一特に放射線 治療之手法の邀応について一. JOHNS 2: 669-673 1986.

13）池田挫：小線源治㙩の適応之限界. JOHNS 6: 242-250 1990.

14）堀内涥一: 治療方針とその選択一放射線治療り 汇場から一. JOHNS 6：207-212 1990.

15）岸啙子, 草間幹夫, 他：舌嗆平上皮瘦 Stage I ・ II 症例の検卻。口科誌 38：1284-1285 1989 (抄). 